\title{
瀧口克已氏の討論に対する回答
}

\section{THE AUTHOURS' ANSWER TO THE DISCUSSION BY PROF. KATSUKI TAKIGUCHI}

(Katsuki TAKIGUCHI, J. Struct. Constr. Eng., AIJ, No.614, 171-172, Apr., 2007)

\author{
金子 佳 生*1, 三 橋 博 三*2, 桐 越一 紀*3, 諏訪内 由紀*4 \\ Yoshio KANEKO, Hirozo MIHASHI, Kazuki KIRIKOSHI \\ and Yuki SUWANAI
}

The authors wish to thank Prof. Katsuki Takiguchi for the discussion. The answers to his questions are as follows:

(1) The yield judgment on steel of $\pm 0.2 \%$-strain is adopted in order to macroscopically clarify the damage-level of cementitious column base and the plasticity-level of steel column

(2) Additional referred papers are required by reviewers in order to clarify the experimental work and the design approach on the proposed column base. In addition, the clear difference between this paper and the referred paper published in June 2005 is identified.

Keywords: Yield judgment, Referred paper

降伏判定、引用論文

\section{1. はじめに}

本研究に関心をお寄せ頂き、贵重なご指摘を頂いたことを感謝致 します。以下にご質問に対する筆者らの回答を述べさせて頂きます。

\section{2. 初期降伏の判定について}

ご指摘の通り、厳密には「降伏点強度をヤング係数で除したひず みを降伏ひずみとするのが一般性を持つ」ことに異論はございませ ん。ただし、本論文で使用しました「鋼材の降伏判定 (p. 182、右下 より1行)」は、あくまでも柱フランジ及び鉄筋の降伏レベルを復元 力特性の中でマクロにとらえるための目安となる指標を設定するこ とを目的としていること、さらに柱フランジと鉄筋の降伏ひずみの 実験值が $0.18 \%$ から $0.2 \%$ であったことに鑑み、一律に $0.2 \%$ と設定し ました。本論文の最大の目的の一つは、通常考えられないレベルま で低くした柱脚接合部に対し、接合部の損傷を軽微もしくは無傷状 態にして、いかに鋼柱の全塑性化を達成するかであり、ここで設定 したマクロな降伏判定でその破壊モードは十分判断出来たと考えて おります。その意図を示すため、言葉足らずであったかもしれませ んが、本論文で、「図中の鋼材の降伏判定は、交番載荷のためひずみ 履歷に依存するが漸増載荷であることより、ここでは目安としてひ ずみが $\pm 0.2 \%$ に達した時点とした。(p.182 右下より 1 行から p. 183 左 上より 2 行)」を記述しました。なお、紙面制限のため一部の試験体 についてのみですが、本論文の図 9(a) (b) (p. 185) に荷重一ひずみ履歴 を用い、マクロな降伏判定と比較して、全荷重履歷における鋼材の 塑性化状態を示しております。

\section{3. 再降伏の力学的意味について}

ご指摘の通り、交番載荷における再降伏時や再々降伏時の判定条 件が厳密に初期降伏ひずみで判定出来ないことは理解しております。 ただし、2.のご指摘に対する回答で述べましたように、ここで定義 しました「鋼材の降伏判定」は、あくまでも復元力特性の中でどの 程度鋼柱の塑性化が進行しているか、またどの程度接合部内の鉄筋 が降伏しているかを確認する為のマクロな指標です。塑性論で考慮 されるモデル化を念頭においたものではなく、ご指摘の「再降伏の 力学的意味」を明確にすることを目的とするものではありません。

\section{4.「特殊な文献」の取り扱いについて}

参考文献 10）、13）、14）は、原論文投稿時には未公開のため、参 考文献に記述していませんでした。查読時に複数の査読委員から、

「本論文と文献 10）の関連性に言及して下さい小「Stapler 筋の設 計方法を示して下さい(文献 13) と関連)」、「柱脚固定度をどのよう に評価するのかを示して下さい(文献 14) と関連)」とのご意見があり、 その時点で全て公開されていたため、これら 3 つの文献を追記しま した。また、本論文と文献 10）の資料と内容が重複しているとのご 指摘ですが、文献 10）は全く補強やアンカーボルトを施さない基本 モデルに対し、どの程度まで接合部の損傷と鋼柱の塑性化が達成さ れるかを確認した基礎実験です。これに対し、本論文は、独自の補 強法を施した応用モデルを提案し、接合高さ、接合部セメント系材 料及び補強方法をパラメータとして、基本モデルと比較しその有用 性を実験的に検証したものです。

（2007年 1 月 9 日原稿受理，2007年 1 月 10 日採用決定）

*1 東北大学大学院工学研究科 助教授 $\cdot P h . D$

*2 東北大学大学院工学研究科 教授. 工博

*3 東北大学工学部 技術職貝

*4 東北大学大学院工学研究科博士前期課程 大学院生
Assoc. Prof., Tohoku University, Graduate School of Engineering, Ph. D Prof., Tohoku University, Graduate School of Engineering, Dr. Eng. Research Assistant, Tohoku University, Faculty of Engineering Graduate Student, Tohoku University, Graduate School of Engineering 